\title{
DEVELOPMENT OF INTERACTIVE MULTIMEDIA TOWARDS ECONOMIC PROBLEMS ON ECONOMIC SUBJECTS FOR SOCIAL SCIENCE CLASS X STUDENTS AT DARMA YUDHA HIGH SCHOOL
}

\author{
SahalaFreddy Simanjuntak ${ }^{1}$, Suarman $^{2}$, Henny Indrawati ${ }^{3}$ \\ (josh.freddy@yahoo.com) \\ Postgraduate Department of Economics Education, Faculty of Teachers Training and \\ Education, Universitas Riau, Pekanbaru, Indonesia
}

\begin{abstract}
This research aims to produce interactive multimedia using Lectora inspire in learning economic using the 4D development model. This work employed a qualitative descriptive method. Interactive multimedia was produced through three stages: definition, design, and development. This research was limited to the development stage. Definition stage comprised the preliminary analysis, curriculum analysis, material analysis, characteristic analysis, and formulation. Meanwhile, the design stage included pre-production from flowchart and storyboard making, media production to final activities: mixing, editing, and finalization. The development stage encompassed the following: (1) Expert appraisal, which was expert validation and revision with a result of very appropriate based on validation of media expert, material expert and language expert, and (2) Developmental testing, consisting of a small-scale tryout with a score of $81.98 \%$ (very appropriate). Our proposed system was very appropriate, according to the result of validation by an expert in a small-scale try-out; thus it can be used in economic learning at SMA Darma Yudha.
\end{abstract}

Keywords: interactive multimedia, development, learning economy.

\section{INTRODUCTION}

A teacher is an agent of social change with a role to direct the mindset, attitudes and behavior of students towards a better, more dignified, and more independent individual (Surya, et al 2010).In order to improve the effectiveness of teaching and learning in the classroom, efforts to improve the understanding of teachers, students and the materials used are essential (HaggartyinMuchayat, 2011). Innovative learning by applying existing technology as a supporting tool, as well as proper preparation and utilization of media, both are expected to stimulate and boost the students' enthusiasm in learning, especially Economics.

One of the media which is expected to motivate students in learning is interactive multimedia. Development of teaching materials is done by teaching staff to solve the 
learning problem by paying attention to the students (target) and adjusting to the competence standard that must be achieved (Haryanto, 2016) while also acts as an innovative product of the teacher. Interactive multimedia is the integration of elements of several media (audio, video, graphics, text, animation, etc.), into a single unit that creates benefits for teachers, students, and other users. The multimedia is used by the teacher to deliver teaching material and as well as building a conducive and motivating atmosphere for the student to learn. Interactive multimedia can be online or offline material. Online interactive multimedia include web, blogs, and other social media; materials in which explored without any requirement to install the application. Offline interactive multimedia are material accessed via computer or mobile phone by firstly installing the application on the device.

Interactive multimedia are prepared with the objective of providing learning material in accordance with the concurrent curriculum, while as well taking into account the needs of students such as individual characteristics and student's surrounding. Interactive multimedia can help students finding alternative learning material, in addition to textbooks which are often considered as "hard to understand/confusing". Well-Designed teaching material should always follow the development of technology, art and life reality in a more and more globalized society (Ho, et al., 2009; Jungnickel, 2009). Interactive multimedia contains files in the form of videos, moving images, or animations and sounds, so that it will be very helpful in the learning process that can help students melt the saturation in the class during learning activities (Diena in Putra, 2017). Interactive multimedia made in the awt format. The creation of interactive multimedia employed the Lectora inspire application. The output of Lectora inspire is presented offline.

The use of interactive multimedia is not limited to teachers' activity, but should also involve students actively in learning. Utilizing media also creates an independent learning process (Sukiminiandari, et al). Interactive multimedia makes teaching orientation can alter the teacher-centric process into student-centric learning. In mediasupported learning, students learn individually in the sense that they can adjust their learning ability with their respective cognition. Students with fast learning ability would complete their learning ahead of their friends without any obstacles from the other lacking. This interactive multimedia encourages students to be more active and innovative in learning.

Learning innovation is imperative to be developed and implemented to prepare students in facing the challenges of Industry 4.0. According to Kennedy et al. (2016), the basic skills necessary to build are critical thinking, problem-solving, collaborative learning, learner-centric and digital literacy teaching. This interactive multimedia development is expected to prioritize students' independence in learning, interest to innovation, and ability to find facts, to help them building concepts and theories with their thinking process and scientific attitudes. 


\section{RESEARCH METHODOLOGY}

This research used the Research and Development (R\&D) model by Thiagarajan, Semmel, and Semmel (1974) consisting of four stages known as a 4-D model. In our study, the 4-D model was modified into 3-D: definition stage, design stage, and development stage. The Disseminate stage is not carried out because it requires too much time and a large number of samples

This research involved Social Science Class X of SMA DarmaYudha as the subject of our research for a limited trial. The research instrument used expert validation sheets and student response questionnaires. Data obtained through questionnaires from media experts, material experts, linguists and student responses in the form of quantitative data and quantitative data. Based on the results of the validator assessment and student response questionnaire, the feasibility of interactive multimedia that has been made can be seen.

The research instrument used expert validation sheets and student response questionnaires. Validation sheets from experts were processed in qualitative data. Student questionnaire responses were processed into quantitative data. 7 validators consist of 2 media experts, 3 material experts, and 3 linguists. The validator for the media is Drs. Said Suhil Achmad., M.Pd (lecturer of FKIP UNRI) and Sonya Meitarice, S.T, M.S.Eng (lecturer of UIN SUSKA). The validator for the material is Dr. Sumarno, M.Pd., M.Si (lecturer of FKIP UNRI), Robert Rivia, S.Pd (economics teacher Senior High School Darma Yudha) and Sri Agustin, S.Pd (MAS teacher Darel Hikmah Pekanbaru). The expert who conducts language validation is Dr. Hermandra, S.Pd., MA (lecturer of FKIP UNRI) and Dr. Hj. Evizariza., M.Hum (lecturer at Lancang Kuning University). Based on the results of the validator assessment and student response questionnaire, it can be seen that interactive multimedia is feasible to be used in learning activities.

\section{FINDINGS AND DISCUSSIONS}

Interactive multimedia for "EconomicProblem" subject had been developed through the 3-D stages, with the following details:

\section{Definition Stage}

In this phase, we conducted five stages of analysis on the needs of students, which were initial analysis, curriculum analysis, student characteristics analysis, concept analysis, and learning objectives analysis. The basic problems identified were that (1) media 
limitations caused the teaching process to be less optimal in which students were less active and dependent on teacher explanations and (2) the unavailability of innovative media development on "Economic Problem" subject which was supposed could guide and help students to learn independently. Based on these problems, it was necessary to develop interactive multimedia to implement PP Nomor 19 Tahun 2017 and curriculum 2013 which requires students to learn independently.

The functions of the define stage determined the learning needs by analyzing the goals and boundaries of the material. Define stage included initial analysis, needs analysis, concept analysis, characteristic analysis, and learning objectives analysis. The explanation of the needs analysis carried out by researchers was in accordance with the steps of needs analysis according to Widodo \& Jasmadi (2008), as cited by Asyhar (2011), as follows (1) establishing competencies that have been formulated in the syllabus; (2) identify and determine the scope of the competency unit or the main competency section; (3) identify and determine the knowledge, skills and attitudes required, and determine the title of the media to be compiled.

Based on the analysis results, it could be seen that in order to achieve learning objectives, specifically on the topic of Economic Problems, interactive multimedia was necessary. This was in accordance with the research of Haniatur Rosyidah (2018) about Pengembangan Multimedia Interaktif Pada Materi Penyelesaian Desain Busana Secara Kering Kelas XI Program Keahlian Tata Busana SMK N 4 Surakarta.

\section{Design Stage}

The design of interactive multimedia should consider the feasibility aspects to be applied in the field. There were three stages in the design stage. The first step was the pre-production stage begins with designing a flowchart and storyboard. We produced a storyline containing teaching material presented in interactive multimedia in this step.

The second step was the production stage; the step of making media in Lectora inspire software starting from collecting materials, making layouts, making icons, inserting text, images, and videos until testing the program. The result was a draft of interactive multimedia.

The third step was the post-production stage. It was an improvement of production including editing, mixing and finalizing the interactive multimedia activities that have been edited. The form of multimedia was an offline autoplay media.

This interactive multimedia design has the following advantages:

1. This interactive multimedia is complemented by interesting interactive practice questions. When answering the questions, students will be connected to the google form application. The application is equipped with an automatic score to appear after completing the test, so students can immediately find out the score of each. 
2. These interactive multimedia has a discussion room connected with the Edmodo application. Teachers and students can interact in the discussion room. Students can ask about the subject matter through the Edmodo discussion room. This media becomes more interesting and interactive.

This statement is reinforced by the theory of Daryanto (2010), explaining that the interactive multimedia Lectora inspire based learning can help in conveying the material in detail and more attractive for students to learn. This product is suitable with the theory in the implementation of learning since it (1) can expand and facilitate access to information in learning quickly; (2) can help visualize abstract material; (3) can display learning the material to be more interesting; and (4) allows interaction with the material being studied.

\section{Development Stage}

This stage of development was a stage with an aim to produce the final product after going through a process of validation, revision, and limited trials in the field. The development stage consisted of two activities, 1) expert appraisal process, which was carried out by media experts, material experts, and language experts, and 2) developmental testing, which was a small-scale test applied to the subject. In this development stage, interactive multimedia was validated by the material experts from the teacher. Based on the results of the assessment and comments/suggestions provided by the expert validation sheet, the next interactive multimedia was revised and then tested limited to the students as users to obtain input directly.

Validation of interactive multimedia products was carried out by three experts, namely media experts, material experts, and language experts. In the development phase, instrument validation was carried out by several experts. There were 7 experts for validation, consisting of 2 media experts, 3 material experts, and 2 language experts. Expert validation aims to obtain input from the expert so that it could be used as an improvement material so that the validity of the resulting product can reach the standard. Assessment by media experts included aspects of design, ease of operation, and the convenience of interactive multimedia. The assessment of material experts comprised the conformity aspects of Basic Competencies and Indicators with the material, the presentation of material that was contextual. Assessment of linguists consisted of sentence structure in accordance with KBBI, the use of words and sentences in the material should be in a standardized form.

Interactive multimedia is considered suitable if the feasibility of the aspects of media, materials, and language reaches $80 \%$ or more (Adaptasi Riduan, 2007). The data from the results of the expert material assessment can be seen in Table 1 . 
Table 1.Expert Validation Assesment Data

\begin{tabular}{llll}
\hline \multirow{2}{*}{ Validator } & \multicolumn{3}{l}{ Assessment Results Validation } \\
& \multicolumn{1}{c}{1} & 2 & 3 \\
\hline Media Expert & $100 \%$ & $83,45 \%$ & $92,5 \%$ \\
Materials Expert & $95 \%$ & $91,67 \%$ & $93,34 \%$ \\
Language Expert & $95,83 \%$ & $93,75 \%$ & $95 \%$ \\
Category & Very Good & \\
\hline
\end{tabular}

Based on the quantitative assessment from Table 1, media experts gave an evaluation of interactive multimedia products by $92.5 \%$, material experts gave $93.34 \%$ ratings, and linguists gave $95 \%$ ratings. That means it's very useful for learning. Nonetheless, revisions were made according to expert advice and feedback.

The suggestions from media experts as improvements, as follows: 1) writing must follow the size of the column, 2) the material presented must be more interesting and simple in the form of important points only, 3) the relevance of the video, 4) the picture with the material displayed, 5) the selection of letters must be correct so that it is easier for students to read, 6) the use of color in writing must be more precise to be comfortable to read and to be more interesting, 7) necessity to add numbers to the navigation menu for operating the media. The results of interactive multimedia in terms of aspects of the media are very feasible to use in the learning process.

The suggestions from material experts as an improvement namely 1) selection of Basic Competencies and Indicators adjusted to the level of student development, 2) the need for HOTS indicators (high order thinking skills), 3) the material must be more to the level of student understanding, 4) the relationship between material one with others, 5) the presentation of the material is adjusted to the development of science and technology, 6) the questions must be more directed to HOTS, 7) the preparation of sentence questions should be adjusted to the circumstances around students by using more contextual language. The results of interactive multimedia in terms of aspects of the material is very feasible to use in the learning process.

The suggestions from linguists as improvements, they include 1) improvement of words, 2) sentences and punctuation used, the media titles used must be replaced because they are not correct, 3) foreign spelling needs to be written in italics, 4) many terms are not appropriate by KBBI such as the use of capital letters, acronyms, and naming. The result of interactive multimedia viewed from aspects of language is very feasible to use in the learning process. 
After passing the validation by media experts, material experts, and linguists and declared suitable to be used as learning media, then interactive multimedia was tested on 10-grade social students. To obtain the results of student responses, students are required to fill in the questionnaire response sheet given when the teacher teaches using interactive multimedia, then the student questionnaire responses were calculated and analyzed.

Based on a limited trial of 21 respondents of class X IPS A of SMA Darma Yudha $2018 / 2019$ academic year, the percentage of the feasibility score in average was $81.98 \%$. This result means that interactive multimedia is very feasible to be utilized as a learning medium on economic subjects. After students' responses were analyzed, the authors also processed the scores which had been collected when students conducted the exercises through the Google Form. From the description of the data above, it can be concluded that the product in the form of interactive multimedia development was very feasible to be utilized by teachers and high school students of Darma Yudha. The author encourages the teachers of Economics and other subjects to apply the interactive multimedia that has been designed. Interactive multimedia is expected to facilitate teacher performance in teaching and motivate students to learn more independently. Display of interactive multimedia products can be seen in Figure 1 and Figure 2.

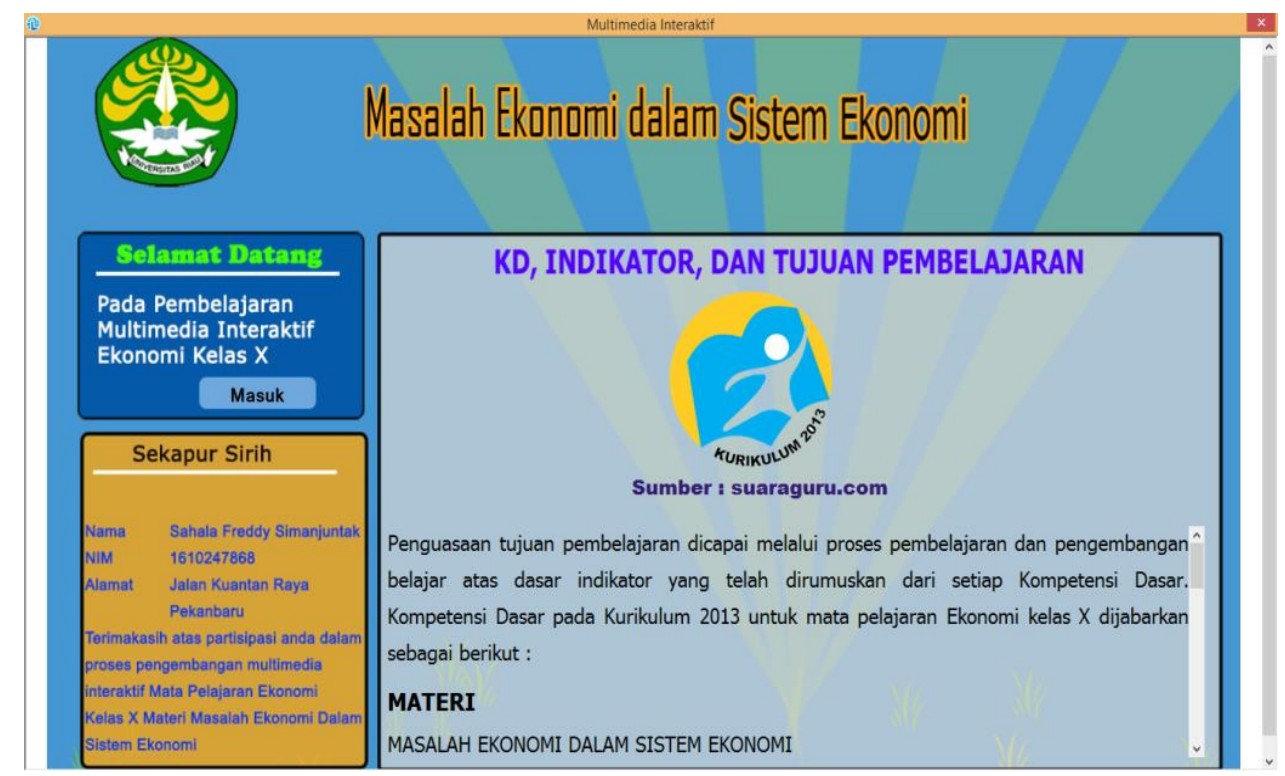

Figure 1. Initial Display of Interactive Multimedia 


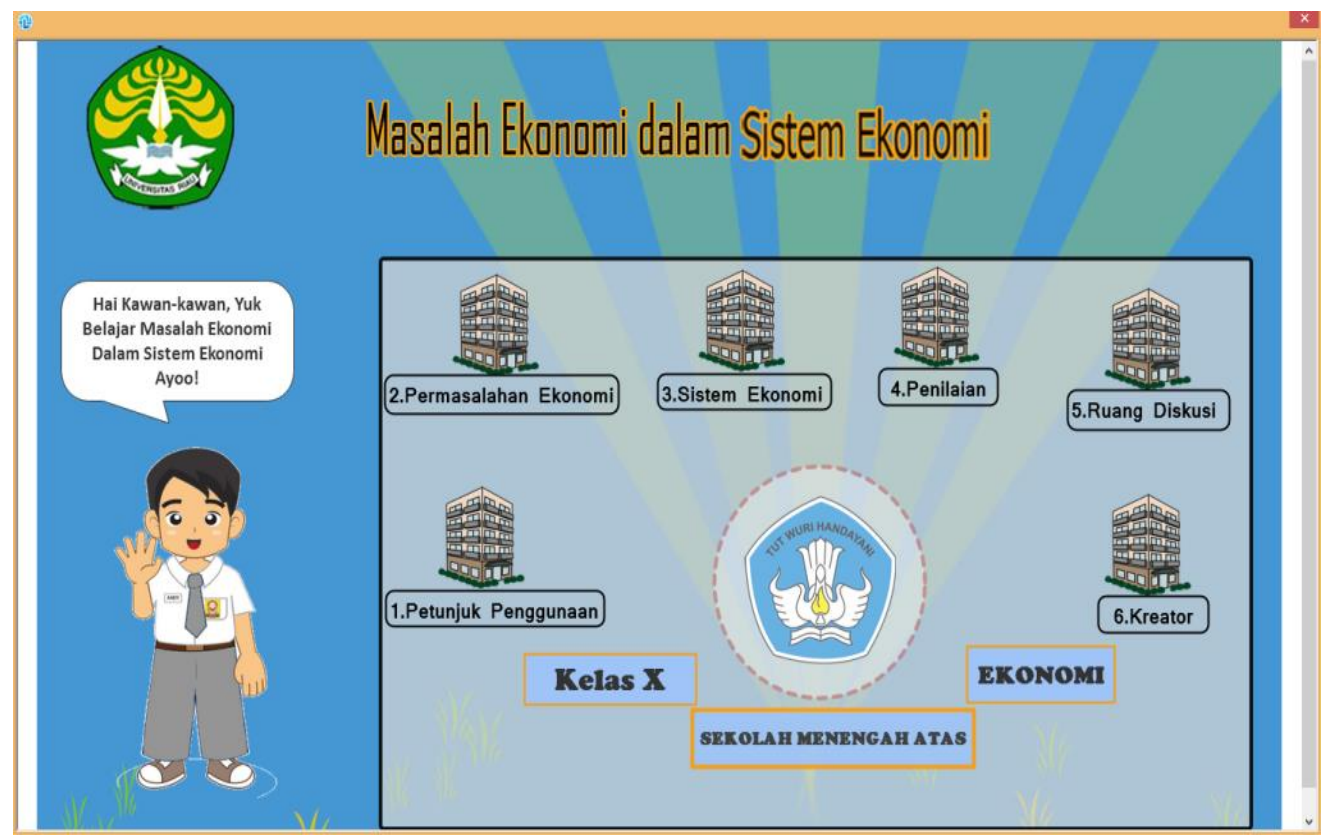

Figure 2. Interactive Multimedia Menu Display

Several studies conducted relating to the development of interactive multimedia in learning can be explained in relevance and comparison as follows:

1. The results of research conducted by Haniatur Rosyidah (2018) about "Pengembangan Multimedia Interaktif Pada Materi Penyelesaian Desain Busana Secara Kering Kelas XI Program Keahlian Tata Busana SMK N 4 Surakarta”. The assessment of media experts with a mean of 93.5 and material experts with a mean of 54 are included in the very feasible category. A small scale trial involving 10 students, averaged 89.9 in the very feasible category. A large scale trial involving 30 students, averaged 86.3 in the very feasible category.

2. The results of research conducted by Manzatinofanie Dwyariessa (2014) with the title "Pengembangan Multimedia Interaktif Tari Luyung Untuk Pembelajaran Seni Tari Siswa SMP". The results of this study are the interactive multimedia of the luyung dance used in the dance learning of junior high school students declared feasible by material experts and media experts. The results of the material expert evaluation obtained an average value of 4 , the results of the evaluation of the media experts obtained an average value of 3.21, and the results of the media evaluation in the field trials received a value of 3.3. The value is $\geq 3$. Thus, Luyung dance interactive multimedia is included in the criteria of good media, so it is declared appropriate to be used.

This study has similarities with using the 4D development model and modified to the 3D stage. But the difference is the researchers created products using the Lectora Inspire application. The advantage of this development research is that the assessment menu is connected to the google form application which contains multiple-choice questions complete with interactive buttons to enable interaction. Provision of questions to the 
media is also equipped with a total score and graduation criteria so that after finishing working on the problem, students can find out the score they have obtained. Then, there is a discussion room between teachers and students through Edmodo application. This media development emphasizes in making interactive multimedia-based media consisting of text, images, animation, sound and video tutorials on economic issues.

\section{CONCLUSION AND RECOMMENDATIONS}

The conclusions are as follows, this interactive multimedia was designed using a modified Research and Development ( $\mathrm{R} \& \mathrm{D})$ model by Thiagarajan, Semmel, and Semmel (1974) with 3D steps. Then the product was validated by the team of experts/academics and student responses through questionnaires were as well treated as an input for validation. The results of the assessment by media experts, material experts, and linguist experts were in the average of $92.5 \%$ (very feasible), $93.34 \%$ (very feasible) and $95 \%$ (very feasible), respectively, and the results of student responses in average were $81.98 \%$ (very feasible). Therefore, interactive multimedia is worthy of being used in learning Economics. In addition, several things need to be improved in order to obtain maximum results when students use this interactive multimedia, including the designing of interactive multimedia with more appropriate writing, material, videos and images, letters, and color to induce comfortable, easy to read, more attractive and easy to operate material. The product should regard to Basic Competencies and Indicators, HOTS Indicators (high order thinking skills), materials, preparation of questions that will facilitate students in understanding the material. The words and sentences, punctuation, foreign spelling, and terms should be according to KBBI. With the improvements mentioned above, students can carry out independent learning both individually and in groups effectively and efficiently.

The recommendations are as follows teacher, besides being able to use interactive multimedia while learning Economics, they can also develop the product for other subjects according to the conditions of the teacher, school, and students. Students as users are expected to utilize interactive multimedia optimally. For further researchers, the effectiveness of interactive multimedia can be examined for student learning achievement. In its use, interactive multimedia can be directly operated on a laptop/computer by installing the application in the first hand. Therefore, further research can publish the multimedia product online without having to install it on a device.

\section{REFERENCES}

Arsyad, A. (2011). Media Pembelajaran. Jakarta. PT Raja Grafindo Persada.

Cahyaningtyas,WA.(2018). Pengembangan Media Pembelajaran Interaktif Berbasis Quantum Learning Untuk Meningkatkan Minat Belajar Dan Pemahaman Konsep 
Fisika Peserta Didik Kelas XI SMA Negeri 1 Depok. Jurnal Pendidikan Fisika.tahun 2018. UNY. Yogyakarta.

Daryanto. (2010).Panduan Proses Pembelajaran Kreatif dan Inovatif. Jakarta. AV Publisher.

Ernawati. (2014). Pengembangan Perangkat Pembelajaran Berdasarkan Model 4-D Pada Materi Getaran Gelombang Dan Bunyi Dalam Meningkatkan Pemahaman Konsep Siswa SMP Negeri 6 Palu, Jurnal Sains dan Teknologi Tadulako, Volume 3 Nomor 1, Januari 2014. Universitas Tadulako. Palu.

Haniatur, Rosyidah.(2018). Pengembangan Multimedia Interaktif Pada Materi Penyelesaian Desain Busana Secara Kering Kelas XI Program Keahlian Tata Busana SMK N 4 Surakarta. Jurnal Pendidikan Teknik Busana,Volume 7 nomor 2. UNY. Yogyakarta.

Haryanto.(2016). "PengembanganBahan Ajar Cetak" dalamApplied Approach (AA)Bukul.UNY Press. Yogyakarta.

Ho, S.S.S, Kember, D, Lau, C.B.S, Yeung, M.Y.M.A, Leung, D.Y.P, dan Chow, M.S.S.(2009). An Outcomes-based Approach to Curriculum Development in Pharmacy, Am J Pharm Educ.

Kennedy I. G, Gloria L, Hélia J. (2016).Education Skills for 21st Century Teachers: Voices Froma Global Online Educators' Forum.SpringerBriefs in Education.London.

Muchayat. (2011). Pengembangan Perangkat Pembelajaran Matematika dengan Stategi Ideal Problem Solving Bermuatan Pendidikan Karakter.Jurnal Penelitian Pengembangan. Volume 1,Nomor 2, Desember 2011. Universitas Negeri Semarang. Semarang.

Peraturan Pemerintah Nomor 19 Tahun 2017. Tentang Standar Nasional Pendidikan.

Putra Bima Firda. (2017).Pengembangan Media Pembelajaran Interaktif Menggunakan Aplikasi Flash Flip Book Tentang Materi Amalia Untuk Peserta Didik Kelas X SMAN 1 Pariaman. Journal Biosains, Volume 1,Nomor 2, 2017. UNP.Padang.

Sukiminiandari, Y.P, Budi, A.S, \& Supriyati, Y. (2015).Pengembangan Bahan ajar Pembelajaran Fisika dengan Pendekatan Saintifik. Prosiding Seminar Nasional Fisika (E-Journal) SNF 2015.UNJ. Jakarta.

Surya, M, Hasim, A. dan Suwarno, R.B. (2010). Landasan Pendidikan:Menjadi Guru yang Baik. Ghalia Indonesia.Bogor.

Thiagarajan, S., Semmel, D.S, Semmel M.I. (1974). Instructional Development for Training Teacher of Exceptional Children: A Sourcebook. Minnepolis: Indiana University. 
Widodo, C, dan Jasmadi.(2008). Buku Panduan Menyusun Bahan Ajar.Jakarta.PT Elex Media Komputindo. 